\title{
In the Beginning...Phylogeny in Freud's Overview of the Transference Neuroses: A Review-Essay
}

\author{
Emanuel E. Garcia, MD \\ Institute of Pennsylvania Hospital, Philadelphia
}

Follow this and additional works at: https://jdc.jefferson.edu/jeffjpsychiatry

Part of the Psychiatry Commons

Let us know how access to this document benefits you

\section{Recommended Citation}

Garcia, MD, Emanuel E. (1988) "In the Beginning...Phylogeny in Freud's Overview of the Transference Neuroses: A Review-Essay," Jefferson Journal of Psychiatry. Vol. 6 : Iss. 2 , Article 15.

DOI: https://doi.org/10.29046/JJP.006.2.015

Available at: https://jdc.jefferson.edu/jeffjpsychiatry/vol6/iss2/15

This Article is brought to you for free and open access by the Jefferson Digital Commons. The Jefferson Digital Commons is a service of Thomas Jefferson University's Center for Teaching and Learning (CTL). The Commons is a showcase for Jefferson books and journals, peer-reviewed scholarly publications, unique historical collections from the University archives, and teaching tools. The Jefferson Digital Commons allows researchers and interested readers anywhere in the world to learn about and keep up to date with Jefferson scholarship. This article has been accepted for inclusion in Jefferson Journal of Psychiatry by an authorized administrator of the Jefferson Digital Commons. For more information, please contact: JeffersonDigitalCommons@jefferson.edu. 


\title{
In the Beginning . . . Phylogeny in Freud's Overview of the Transference Neuroses: A Review-Essay
}

\author{
A PHYLOGENETIC FANTASY \\ I. Grubrich-Simitis, editor
}

A. Hoffer and P. T. Hoffer, translators

Harvard University Press, Cambridge, Mass.

1987

Emanuel E. Garcia, M.D.

The recent discovery of Freud's unpublished paper, "Overview of the Transference Neuroses",(1) focuses attention once again on the intriguing role of phylogeny, the evolutionary development of species, in psychoanalytic thought. To those who are apt to dismiss the prominent phylogenetic concerns of Totem and Taboo (Freud, 1913) and Moses and Monotheism (Freud, 1939) as unnecessary aberrations, the "Overview" is sure to give pause. It stresses clearly that for Freud phylogeny was no passing fancy, but an essential topic of interest forced upon him by insoluble clinical riddles.

At the outset, however, one must acknowledge the overriding fact that, for reasons which are unknown, Freud deliberately refrained from publishing the "Overview." Consequently, extreme caution in the application or assimilation of the new material must be urged. No doubt, in keeping with Eissler's eloquent argument (1951), we should regard the unearthing and preservation of any document of Freud's as a matter of significance; but the "Overview" remains an element that is outside Freud's scientific corpus proper.

A few words about the discovery of this unique work and the context in which it was composed are in order.

While rummaging through papers bequeathed by one of the early pioneers of psychoanalysis, Sandor Ferenczi, to his Hungarian compatriot Michael Balint, Dr. Ilse Grubrich-Simitis chanced upon a manuscript which she soon realized was the draft of one of the long-missing metapsychological papers which Freud

\footnotetext{
'The English language edition is misleadingly entitled "A Phylogenetic Fantasy" (Freud, 1987). Translators Axel and Peter Hoffer, who otherwise appear to have done an excellent job, have taken an unwarranted liberty by imposing such a title. The German version, however, "Übersicht der Übertragungsneurosen," (Freud, 1985), happily remains faithful to the original document. Afl page numbers cited refer to the English edition.
} 
composed during the gloomy days of World War I (Grubrich-Simitis, 1987a, pp. $\mathrm{xv}-\mathrm{xvii}$.

In the short space of six months -- from March to August 1915 -- Freud wrote twelve papers whose purpose, as a series, was "to clarify and carry deeper the theoretical assumptions on which a psycho-analytic system could be founded" (Freud, 1917a, p. 222). Only the first five, completed by May 1915, found their way into print. ${ }^{(2)}$ The remaining papers were presumed to have been destroyed by their author, and purportedly dealt with the topics of consciousness, anxiety, conversion hysteria, obsessional neurosis, sublimation and projection, and the transference neuroses (see Strachey, 1957, p. 106; and Jones, 1955 , pp. 185-186). Such an outburst of creativity in so brief a period of time is astonishing, the more so when one considers the profundity of the published results. In fact, even Freud - a severe critic of his own work-placed one of the compositions, "The Unconscious," among his three most enduring achievements (Jones, 1956).

But why did he withhold the last seven essays? Jones ventures a guess:

My own supposition is that they represented the end of an epoch, the final summing up of his life's work. They were written at a time when there was no sign of the third great period in his life that was to begin in 1919. He probably kept them until the end of the war, and then when further revolutionary ideas began to dawn which would have meant completely re-casting them he simply tore them up (1955, p. 186).

No doubt other speculations will be provoked by the mystery, but for the time being we must resign ourselves to uncertainty.

The "Overview," the draft of which Dr. Grubrich-Simitis so fortunately salvaged from oblivion, was the final work of the series-its crown jewel, so to speak. It appears to have represented the consummation of Freud's theoretical views on the development of the neuroses. In fact, its very title was provisionally intended by Freud for the series as a whole (Jones, 1955, p. 185).

The summary that follows is an admittedly skeletal one that does not do justice to the dense complexity of the "Overview." In the interests of a broad delineation of selected issues, I have sacrificed detail. Furthermore, I have made little effort to update or explicate older terminology, because such technicalities are outside the realm of my emphasis. For these shortcomings I beg the reader's indulgence in advance.

Freud proclaims his purpose in the "Overview" at the outset: to investigate in a systematic and comparative way the role of six major factors in the so-called transference neuroses-anxiety hysteria, conversion hysteria, and obsessional

"They are: "Instincts and their Vicissitudes" (1915a), "Repression" (1915b), "The Unconscious" (1915c), "A Metapsychological Supplement to the Theory of Dreams" (1917a), and "Mourning and Melancholia" (1917b). 
neurosis. Thus, his phylogenetic speculations, as we will see, are firmly placed within this specific context; they do not constitute the raison d'etre of the work, as the unfortunately fabricated title of the English version would imply. The factors in question are (1) repression, (2) anticathexis, (3) substitute- and symptom-formation, (4) regression, (5) relation (of the neuroses) to the sexual function, and (6) disposition. Freud's discussion of the first five factors is written in a sort of shorthand, and much of this ground appears to have been covered in the earlier papers, though not with the same sense of comparative summary.

Freud's exertions are palpable. We see him arduously struggling to build a coherent theoretical edifice on the unyielding bedrock of clinical data. Indeed, instead of the ethereal speculation that has come to stigmatize not only much psychoanalytic metapsychology but also abstract theorizing in general, one is impressed by Freud's close grounding in first-hand material, his strenuous attempt to elaborate a theory of the mind spawned by and faithful to clinical experience. The permeation of Freud's metapsychological writings by the hard facts of observational data is a distinguishing feature.

Nevertheless, this portion of the essay is highly technical and highly condensed; though a rich lode for the Freud scholar or inquisitive psychoanalytic theorist, it makes for difficult reading. However, with the section on the disposition to the neuroses, Freud's terse, abbreviated style finally gives way to elaborative prose. The fixations in ego or libido development that dispose one to particular neuroses may be explained by a combination of infantile acquisitions and constitutional factors. Freud's inquiry into the etiology of these constitutional factors draws him ineluctably to the intriguing obscurities of phylogeny.

Asserting that "the inherited dispositions are residues of the acquisitions of our ancestors" (p. 10), and that the neuroses somehow "bear witness to the history of the mental development of mankind"' (p. 11), Freud embarks on a fascinating retrospective reconstruction of the prehistory of the human race. And in preparation for the remarkable material he would introduce, Freud asks his readers to "be patient if once in a while criticism retreats in the face of fantasy and unconfirmed things are presented, merely because they are stimulating and open up distant vistas" (p. 11).

Freud contrasts the transference neuroses (anxiety hysteria, conversion hysteria, and obsessional neurosis) with the "narcissistic" neuroses (psychotic disorders, e.g., dementia praecox, paranoia, melancholia-mania, in his lexicon); and after arranging them on a series representing age of onset in the individual's life-span, he purports to discern parallels to stages in the evolutionary development of mankind. In essence, Freud avers, the behavior of the species during periods of its phyletic development resembled the behavior of present-day neurotics.

For example, the privations occasioned by the Ice Ages created in mankind a general state of anxiety comparable to that of the person suffering from anxiety hysteria. As difficulties mounted and man's very existence was threatened by the ensuing scarcity of life-sustaining resources, unrestricted procreation came to be 
a danger to the species' survival. As a consequence, sexual activity was diverted into nonprocreative or "perverse" channels, promoting thereby a pregenital libidinal regression. The equivalent of this stage was found in conversion hysteria, which itself embodies the conflict between self-preservative and procreative wishes in the neurotic.

In the next stage, man's intellectual activity became all-important:

He learned how to investigate, how to understand the hostile world somewhat, and how by means of inventions to secure his first mastery over it. He developed himself under the sign of energy, formed the beginnings of language, and had to assign great significance to the new acquisitions. Language was magic to him, his thoughts seemed omnipotent to him, he understood the world according to his ego. It is the time of the animistic world view and its magical trappings. As a reward for his power to safeguard the lives of so many other helpless ones he bestowed upon himself unrestrained dominance over them, and through his personality established the first two tenets that he was himself invulnerable and that his possession of women must not be challenged. At the end of this epoch the human race had disintegrated into individual hordes that were dominated by a strong and wise brutal man as father (pp. 15-16).

This phase is recapitulated by obsessional neurosis, which is characterized by the belief in the omnipotence of thought and by the neurotic's tremendous expenditure of energy which, falling prey to psychic conflict, no longer contributes to the development and enhancement of civilization, but is instead consumed by uselessly trivial compulsions.

Freud grows even more bold and more daring with his consideration of the narcissistic neuroses and the phylogenetic epochs they represent.

The dispositions to dementia praecox, paranoia and melancholia-mania, Freud asserts, must have been acquired by a second generation, sons of the primal father, heralding a new phase in civilization. Revising and extending ideas introduced in the notorious Totem and Taboo (1913), Freud claims that the primal father did not merely drive his sons out of the horde when they reached puberty; he actually castrated them, after which he allowed their return as drones. The result of the gruesome deed- "an extinguishing of the libido and a standstill in individual development" (p. 17) - finds its equivalent in dementia praecox, which is itself a condition characterized by the abandoment of loveobjects and the regression to auto-erotism. (Freud cautions us not to let the hallmark of schizophrenia, the withdrawal from external reality, be obscured by its more florid or dramatic symptomatology such as hallucinations, which are secondary restitutive phenomena, i.e., attempts to reestablish a connection with the world.)

Those who escaped castration by flight banded together to form a homosexually-based social organization which fostered paranoia, the projective defense against homosexuality. 
Melancholia-mania recalls the elation and mourning that occurred after the organization of brothers succeeded in murdering their despotic paternal overlord. Only the youngest sons, by dint of their father's advancing age and physical debility, could avoid the fate of their older brothers; and it was they who eventually succeeded their progenitor as new leaders.

Freud summarizes his phyletic argument as follows:

If the dispositions to the three transference neuroses were acquired in the struggle with the exigencies of the Ice Age, then the fixations that underlie the narcissistic neuroses originate from the oppression by the father, who after the end of the Ice Age assumes, continues its role, as it were, against the second generation. As the first struggle leads to the patriarchal stage of civilization, the second (leads) to the social; but from both come the fixations which in their return after millennia become the disposition of the two groups of neuroses. Also in this sense neurosis is therefore a cultural acquisition. The parallel that has been sketched here may be no more than a playful comparison. The extent to which it may throw light on the still unsolved riddle of the neuroses should properly be left to further investigation, and illumination through new experiences (p. 19).

Freud alertly anticipates some critical objections. How do women, who are no less predisposed than men toward the narcissistic neuroses, come to acquire their hereditary dispositions? And how in the second generation can the castrated or homosexual sons pass on their traits? After acknowledging that the role of women in primal times is obscure to him, he calls upon the fact of human bisexuality as an explanation of inherited neurotic tendencies in females. And he proposes that the youngest sons, who had been impressed by the horrid fate of their brothers, but who retained the ability to propagate, became the vehicles for hereditary transmission.

Freud concludes the paper with an admission of the difficulties posed by his scenario, and the admonition that "we are not at the end, but rather at the beginning, of an understanding of this phylogenetic factor”' (p. 20).

Many readers will be tempted simply to dismiss the phylogenetic portion of the "Overview" as an elaborate fairy tale, scientifically worthless if not wholly preposterous. I would caution against adopting such an attitude, if only because facile disparagement of the efflorescences of genius, however bizarre or unlikely they may appear at first glance, might well deprive mankind of significant scientific treasure. It is a well-known historical fact that original and revolutionary ideas typically evoke derisive contempt: the fiery and acrimonious response to Darwin's theory of evolution is a case in point. Prevailing prejudices are enormously difficult to dislodge.

Fortunately, so eminent an evolutionary biologist and historian as Stephen Jay Gould (1987), takes Freud very seriously indeed, and it behooves us to consider his own assessment of the "Overview" if only to achieve an understanding of Freud's biological shortcomings from an expert's point of view. 
Gould identifies the "biological linchpins" of Freud's phylogenetic hypothesis in the theory of recapitulation (ontogeny recapitulates phylogeny), and Lamarckism (inheritance of acquired characteristics). ${ }^{(3)}$ The former "allowed Freud to interpret a normal feature of childhood (or a neurosis interpreted as fixation to some childhood stage) as necessarily representing an adult phase of our evolutionary past" (p. 18); the latter permitted him to assume that "Any important and adaptive behavior displayed by adult ancestors can pass directly into the heredity of offspring -- and quickly" (p. 18). Both theories, though acceptable to biologists of Freud's era, have long since been vitiated and abandoned. (By the way, Gould [1977] has written the definitive modern study of Haeckel and the theory of recapitulation.)

Gould admires the logical consistency of Freud's argument, relying as it does on two formerly respectable, though presently discredited, ideas. Yet he levels a number of telling criticisms: Freud's view is overly adaptationist, ${ }^{(4)}$ falsely Eurocentric, and devoid of historical or archaeological evidence. The Ice Age did not bring undue suffering to European Neanderthals (who were not the ancestors of homo sapiens anyway), and no data support the existence of prehistoric social organizations consisting of primal hordes dominated by castrating fathers.

All in all, Gould's criticisms would appear impervious to rebuttal, coming as they do from such an authority on evolutionary development. Yet for all their apparent "correctness," they simply miss the mark. They resemble the comments of someone who, from the distance of several inches, finds fault with a Van Gogh study, with its aberrant colors and unconventional brushstrokes. One needs to stand back a bit to appreciate the work's power and potential importance.

The "Overview," however faulty its linchpins, is significant because it focuses our attention on essential aspects of Freud's general thought. The evolutionary history of man was a necessary, ongoing and prominent concern of Freud's psychoanalytic investigations throughout his life. Freud envisioned man in an eminently Darwinian context: one species among many, whose physical and mental features were molded over the ages by the earthly environment. He writes:

Man is not a being different from animals or superior to them; he himself is of animal descent, being more closely related to some species and more distantly to others. The acquisitions he has subsequently made have not succeeded in effacing the evidences, both in

\footnotetext{
${ }^{3}$ See Paul's (1976) discussion of Freud's “Lamarckist" tendencies (pp. 319-320).

4" In our tough, complex, and partly random world, many features just don't make functional sense, period. We need not fob them off on an old adaptation that has become unhinged. We need not view schizophrenia, paranoia and depression as postglacial adaptations gone awry: perhaps they are immediate pathologies, with remediable medical causes pure and simple" (1987, p. 19).
} 
his physical structure and in his mental dispositions, of his parity with them (1917c, p. 141; my italics).

The mind, no less than the body, has been subject to evolutionary forces and displays the residues of its long heritage in our own "modern" times. It is only fitting that the origin of its dispositions should be subjected to examination.

In fact, Freud found himself compelled to consider phylogenetic factors when clinical investigation demonstrated the operation of persistent forces that could not be accounted for by an individual's actual experiences. For example, in his famous case history of the Wolf-man, Freud attempts to account for his patient's identification of his father as castrator thus:

At this point the boy had to fit into a phylogenetic pattern, and he did so, although his personal experiences may not have agreed with it. Although the threats or hints of castration which had come his way had emanated from women, this could not hold up the final result for long. In spite of everything it was his father from whom in the end he came to fear castration. In this respect heredity triumphed over accidental experience; in man's prehistory it was unquestionably the father who practised castration as a punishment and who later softened it down into circumcision (1918, p. 86; my italics).

And while discussing male oedipal development, Freud asserts that the castration threats of the phallic phase "must regularly find a phylogenetic reinforcement" in the little boy (1933a, p. 86). In other words, his clinical material did not convince him that environmental factors could sufficiently explain the universality and intensity of castration anxiety. The implication here is that in the hypothetical case of a boy brought up without any threat of castration, conscious or unconscious, castration anxiety would nevertheless arise owing to the unfolding manifestation of a phylogenetic residue in the psyche.

As anthropologist Robert Paul (1976) summarizes in a perspicacious essay on the "primal crime,"

the idea of phylogenetically transmitted ideas was forced upon him [Freud] because he kept encountering in his patients reactions to events or knowledge of things that seemed unlikely to have been acquired through experience. . . . Freud did not believe in inherited memories until he had empirically accumulated evidence that forced him to come to that conclusion (pp. 322-323).

Freud's position is completely consonant with that of a present-day psychiatrist who, let us say, partially attributes to genetic factors the occurrence of bipolar disorder in a patient. Speaking of an inherited disposition that manifests itself in ideas, images or psychic tendencies is quite compatible with our modern science of genetics: these are merely phenotypic expressions of genetic endowment in the psychological sphere. 
Freud's phylogenetic reconstruction, right or wrong, is simply an attempt to establish the ultimate origin of psychological forces, based on the assumption that "disposition is ultimately the precipitate of earlier experience of the species to which the more recent experience of the individual, as the sum of the accidental factors, is super-added"' (Freud, 1905, p. 131). Even Gould (1977) admits that some relationship between ontogeny and phylogeny has to exist:

Evolutionary changes must be expressed in ontogeny, and phyletic information must therefore reside in the development of individuals (p. 2).

But Gould betrays his psychological naivete when he accuses Freud of being too "adaptationist." What is explicit in many of Freud's works (see, for example The Psychopathology of Everyday Life [1901]), and implicit in the "Overview," is that neurotic mental tendencies or mechanisms are universal. And given their universality, it is eminently justifiable to postulate that they once served an important function for the species. Grubrich-Simitis (1987b) rightly stresses the continued relevance of considering

whether what strikes us today as pathological and life inhibiting in the inner world of the neurotic and psychotic could have been an adaptive reaction of the species, necessary for its survival, to threatening changes in the external conditions of life and traumatic events in its evolutionary beginnings (p. 107) ${ }^{(5)}$

And although Freud clearly professes unwavering belief in the biological transmission of acquired characteristics (1939, p. 100), and Gould (1987) castigates him for this position, so opposed to modern biological science, this does not impair his general argument that the relatively recent events of prehistory have contributed significantly to innate psychological development. Non-genetic cultural transmission remains a very potent force. By means of conscious and, more importantly, unconscious symbolic communication, the child may be powerfully impressed by certain psychic schemata which his own unconscious can decode and assimilate (see Paul, 1976, pp. 318-319). Freud writes that

no generation is able to conceal any of its more important mental processes from its successors. For psycho-analysis has shown us that everyone possesses in his unconscious mental activity an apparatus which enables him to interpret other people's reactions, that is, to undo the distortions which other people have imposed on the expression of their feelings (1913, p. 159).

As an unconscious bearer of knowledge, the individual will in turn transmit such knowledge unawares to the next generation, who will repeat the process, and so on. ...

${ }^{5}$ See Nesse (1988) for an evolutionary view of panic disorder. 
Thus, dramatic events with widespread cultural impact can be generally assimilated and symbolically perpetuated from generation to generation, with profound effects. Consequently, occurrences of the relatively near past may leave lasting psychic impressions. Inheritance need not be confined to the genome: the transmission of acquired characteristics may be accomplished via a cultural route. Nevertheless, we still cannot escape the implacable fact that, to quote Freud quoting Goethe, "in the beginning was the Deed" (Freud, 1913, p. 161).

The great question Freud asks is: What actual circumstances gave rise to the evolution of man's peculiar psychological characteristics? Using psychoanalysis as an applied research tool, he gropes, ever the pioneer, for an answer.

A truly adequate discussion of the role of phylogeny in Freud's scientific work would require a substantial treatise. ${ }^{(6)}$ Suffice it to say that phylogeny is implicated in Freud's consideration of drives and defense mechanisms; sexuality, the latency period, and the Oedipus complex; id, ego and superego development; memory and fantasy formation; religion and culture; symbolism, dreaming and the etiology of the neuroses and psychoses (see the bibliographic appendix for a guide to some of Freud's phylogenetic references). Obviously so prominent a topic deserves careful evaluation.

The "Overview," despite its technical shortcomings and its failure to have achieved the imprimatur of its author, compels us to confront, perhaps more closely than ever, issues that seem scarcely accessible to our feeble scientific powers. After all, there is no more profound challenge than that posed by the riddle of human origins. The "Overview" joins Freud's many other writings in demonstrating that "psycho-analysis may claim a high place among the sciences which are concerned with the reconstruction of the earliest and most obscure periods of the beginnings of the human race" (Freud, 1900, p. 549).

And if there are doubts about the relevance of such a focus, we need only remind ourselves that ignorance of the primaeval past, our fons et origo, will merely condemn us to repeat it.

\section{REFERENCES}

1. Eissler KR: An unknown autobiographical letter by Freud and a short comment. Int J Psychoanal, 32:319-324, 1951

2. Freud S: The interpretation of dreams. SE, 4 \& 5, 1900

3. Freud S: The psychopathology of everyday life. SE, 6:1-279, 1901

4. Freud S: Three essays on the theory of sexuality. SE, 7:130-243, 1905

5. Freud S: Totem and taboo. SE, 13:1-161, 1913

6. Freud S: Instincts and their vicissitudes. SE, 14:117-140, 1915a

7. Freud S: Repression. SE, 14:146-158, 1915b

8. Freud S: The unconscious. SE, 14:166-204, 1915c

${ }^{6}$ For introductory forays into this topic see Grubrich-Simitis (1987b), and Paul (1976). 
9. Freud S: A metapsychological supplement to the theory of dreams. SE, 14:222-235, $1917 \mathrm{a}$

10. Freud S: Mourning and melancholia. SE, 14:243-258, 1917b

11. Freud S: A difficulty in the path of psycho-analysis. SE, 17:137-144, 1917c

12. Freud S: From the history of an infantile neurosis. SE, 17:7-122, 1918

13. Freud S: New introductory lectures on psycho-analysis. SE, 22:5-182, 1933

14. Freud S: Moses and monotheism. SE, 23:7-137, 1939

15. Freud S: Übersicht der Übertragungsneurosen, ed I. Grubrich-Simitis. Frankfurt am Main, SF Fischer Verlag, 1985

16. Freud S: A Phylogenetic Fantasy, ed I. Grubrich-Simitis, trans. A Hoffer \& PT Hoffer. Cambridge, Mass, Harvard Univ Press, 1987

17. Gould SJ: Ontogeny and Phylogeny. Cambridge, Mass: Harvard Univ Press, 1977

18. Gould SJ: Freud's phylogenetic fantasy. Natural History, 96(12):10-19 (December 1987), 1987

19. Grubrich-Simitis I: Preface to Freud, S, A Phylogenetic Fantasy, ed I. GrubrichSimitis, trans. A Hoffer \& PT Hoffer, Cambridge, Mass, Harvard Univ Press, $1987 \mathrm{a}$

20. Grubrich-Simitis I: Metapsychology and metabiology, in Freud, S, A Phylogenetic Fantasy, ed I. Grubrich-Simitis, trans. A Hoffer \& PT Hoffer, Cambridge, Mass: Harvard Univ Press, pp 75-113, 1987b

21. Jones E: The Life and Work of Sigmund Freud, vol 2. New York, Basic Books, 1955

22. Jones E: The inception of 'Totem and Taboo.' Int J Psychoanal, 37:34-35, 1956

23. Nesse RM: An evolutionary view of panic disorder. Psych Annals, 18:478-483, 1988

24. Paul RA: Did the primal crime take place? Ethos 4:311-352, 1976

25. Strachey J: Editor's introduction to Papers on Metapsychology. SE, 14:105-107, 1957

\section{APPENDIX}

Selected List of Freud's References to Phylogeny

(page numbers indicating specific passages, where appropriate, are in parentheses)

1. (1898) Sexuality in the aetiology of the neuroses. SE, 3:263-285 (pp 280-281)

2. (1900) The interpretation of dreams. SE, 4 \& 5 (pp 548-549)

3. (1905) Three essays on the theory of sexuality. SE, 7:130-243 (pp 131, 234, 241)

4. (1911) Psycho-analytic notes on an autobiographical account of a case of paranoia (dementia paranoides). SE, 12:12-82 (pp 74, 82)

5. (1913a) Totem and taboo. SE, 13:1-161

6. (1913b) The claims of psycho-analysis to scientific interest. SE, 13:165-190 (pp 182-186)

S.E. = Standard Edition of the Complete Psychological Works of Sigmund Freud. London: Hogarth Press. 
7. (1915a) Instincts and their vicissitudes. SE, 14:117-140 (pp 120-125, 131)

8. (1915b) Thoughts for the times on war and death. SE, 14:275-300 (pp 292-296)

9. (1916-17) Introductory lectures on psycho-analysis. SE, 15 \& 16 (pp 199-210, $354-355,366,370-371,378,395-396,413-414)$

10. (1917) A difficulty in the path of psycho-analysis. SE, 17:137-144 (pp 140-141)

11. (1918) From the history of an infantile neurosis. SE, 17:7-122 (pp 41, 86-87, 97, 102-103, 119-121)

12. (1919a) 'A Child is Being Beaten': a contribution to the study of the origin of sexual perversions. SE, 17:179-204 (pp 188, 193, 203-204)

13. (1919b) Preface to Reik's Ritual: Psycho-Analytic Studies. SE, 17:259-263 (p 262)

14. (1920) Beyond the pleasure principle. SE, 18:7-64

15. (1921) Group psychology and the analysis of the ego. SE, 18:69-143

16. (1923a) Two encyclopaedia articles. SE, 18:235-259 (pp 246, 252-253)

17. (1923b) The ego and the id. SE, 19:12-66 (pp 21, 35-39, 48-49, 55)

18. (1923c) A Seventeenth-century demonological neurosis. SE, 19:72-105 (p 85)

19. (1924a) Neurosis and psychosis. SE, 19:149-153 (p 151)

20. (1924b) The dissolution of the oedipus complex. SE, 19:173-179 (p 174)

21. (1925a) Some additional notes on dream-interpretation as a whole. SE, 19:122-138 (p 135)

22. (1925b) The resistances to psycho-analysis. SE, 19:213-222 (pp 220-221)

23. (1925c) Some psychical consequences of the anatomical distinction between the sexes. SE, 19:248-258 (p 257)

24. (1926a) Inhibitions, symptoms and anxiety. SE, 20:87-174 (pp 146-155)

25. (1926b) Psycho-analysis. SE, 263-270 (p 268)

26. (1927) The future of an illusion. SE, 21:5-56 (p 17)

27. (1930) Civilization and its discontents. SE, 21:64-145 (pp 103, 131, 144)

28. (1933a) New introductory lectures on psycho-analysis. SE, 22:5-182 (pp 55, 79, 86-87)

29. (1933b) Sandor Ferenczi. SE, 22:227-229

30. (1939) Moses and monotheism. SE, 23:7-137

31. (1940) An outline of psycho-analysis. SE, 23:144-207 (pp 153, 167, 188-190, 201, 206-207)

32. (1987) A Phylogenetic Fantasy, ed I. Grubrich-Simitis, trans A Hoffer \& PT Hoffer. Cambridge, Mass, Harvard Univ Press 